\title{
Globalization and Language Policies of Multilingual Societies: Some Case Studies of South East Asia
}

\section{Globalização e políticas linguísticas em sociedades multilingues: Estudos de caso do sudeste da Asia}

\author{
Navin Kumar Singh* \\ Northern Arizona University \\ Flagstaff / USA \\ Shaoan Zhang** \\ University of Nevada \\ Las Vegas / USA \\ Parwez Besmel*** \\ Northern Arizona University \\ Flagstaff / USA
}

\begin{abstract}
Over the past few decades, significant economic and political changes have taken place around the world. These changes also have put a significant mark on language teaching and learning practices across the globe. There is a clear movement towards multilingual practices in the world, which is also evident in the title of UNESCO 2003 education position paper, "Education in a multilingual world." Given the long-standing history of multilingual contexts of the Himalayan region and the emergence of the two major global economic power centers of $21^{\text {st }}$ century, China and India, language policies and practices of the region have become a great matter of interests for linguists and policy makers around the world. This paper uses case studies to investigate how globalization influences language education policies and practices in multilingual countries. The case studies that we have drawn from the four nations of South East Asia - Afghanistan, China, India, and Nepal offer insights for other multilingual nations of the world, as they portray the influences of globalization on language policies and practices of multilingual countries. This paper suggests more research on comparative studies of multilingual education across multilingual nations in the world.
\end{abstract}

KEYWORDS: Language maintenance, globalization, multilingualism, Asian societies.

\footnotetext{
*nks23@nau.edu

**shaoan.zhang@unlv.edu

***pb75@nau.edu
} 
RESUMO: Nas últimas décadas, transformações econoômicas e políticas significativas transcorreram no mundo. Essas mudanças deixaram sua marca também nas práticas de ensino e aprendizagem de línguas em todo o globo. Há um claro movimento em prol de práticas multilíngues, o que fica evidente no título do artigo de posição da UNESCO sobre a educação de 2003, "Education in a multilingual world”. Frente à longa história de contextos multilíngues na região do Himalaia e à emergência de duas potências mundiais no século 21 , a Índia e a China, as práticas e políticas linguísticas da região tornaram-se assunto de grande interesse para linguistas e legisladores de todo o mundo. Este artigo contempla estudos de caso para investigar como a globalização influencia as políticas e práticas de educação linguística em países multilíngues. Os estudos de caso aqui destacados, oriundos de quatro nações do sudeste asiático, Afeganistão, China, Índia e Nepal, oferecem insights para outras nações multilíngues do mundo, por representar os impactos da globalização nas práticas e políticas linguísticas dos países multilíngues. $\mathrm{O}$ artigo sugere mais pesquisas e estudos comparativos sobre a educação plurilíngue nas nações multilíngues do mundo.

PALAVRAS-CHAVE: Manutenção linguística, globalização, multilinguismo, sociedades asiáticas.

\section{Introduction}

In the past three decades, significant economic and political changes have occurred all across the globe. Consequently, cross-cultural contact is at an all time high in human history, as physical and geographical boundaries are shrinking day-by-day (KUMARAVADIVELU, 2008; SPOLSKY, 2009; WRIGHT, 2004; ZAKARIA, 2011). These changes have also affected language education policies and practices, as multilingualism has become a common phenomenon all across the globe. To date, around 200 countries in the world recognize two or more official languages (e.g., Canada, India, Luxembourg, Nigeria, Singapore, Hong Kong SAR of China, Malaysia, and South Africa). However, a small number of languages including Arabic, Bengali, English, French, Hindi, Malay, Mandarin, Portuguese, Russian, and Spanish are also used as lingua-franca or languages of wider communication across the globe. These languages are also often spoken as second, third, fourth, or later-acquired languages (DE SWAAN, 2001; SPOLSKY, 2009; TUCKER, 1999; WRIGHT, 2004).

The recent trend of "globalization" gained popularity in the 1980s when the first and the last president of the Soviet Union, Mikhail Gorbachev, introduced his open door policy in terms of glasnost and perestroika. As he once said, "The market is not an invention of capitalism. It has existed for centuries. It is an invention of civilization." However, the notion of globalization is not 
new since it has been rugged in many different ways throughout the centuries in terms of slavery, colonization, missionary activities, and alliances, such as NATO, WARSAW PACT, Non Align Movement (NAM), League of Nations, United Nations Organization, and Common Wealth are few to name.

With the advent of globalization, English language continues to grow as a second or third language in many parts of the world. Mohd-Asraf (2005) states that, "[a]s an international and a world language, its influence spans the entire globe, and there is hardly any country today that does not use English in one way or another or that is not affected by its spread" (p. 103). The increasing use of English as a second or third language is making changes in language education in the countries with linguistic minorities and indigenous communities.

According to De Swaan (2001), who presents the organization of languages and their relationships in a global context, "[i]t is multilingualism that has kept humanity, separated by so many languages, together...It is this ingenious pattern of connections between language groups that constitutes the global language system" (p. 1). He adds that at the bottom of this system are the world's many small languages that he called peripheral languages. Peripheral languages constitute $98 \%$ of the world's languages and are used by under $10 \%$ of the population of the world. Often these languages have no written script, and are passed on orally and rely on people remembering them rather than recording them. At the next level, connecting peripheral languages, are central languages (e.g., Chinese, Hindi, and Russian). There are about 100 central languages in the world and they are acquired as second languages by speakers of peripheral languages. Central languages are often national or official languages and are used in politics, courts, education systems, television, textbooks and newspapers (DE SWAAN, 2001, p. 5-6). For Hamel (2005), multilingualism is not only requisite for ecological sustainability, but it is also as anindividual and collective asset.

Much has been written on the influence of globalization on culture, politics and the economy, but its impact on language education policies and practices has hardly been presented. This paper presents some case studies from South-East-Asia in terms of language policies and planning, with reference to bilingualism/multilingualism in the changed contexts of a globalized world. There is a clear movement towards multilingual practices in the world within the last two or three decades. Given the long-standing history of multi-ethnic and linguistic diversity of South-East-Asia, where India and China, the two emerging power centers, are geographically located, this paper offer cases in 
which language policies and planning of multi-ethnic and diverse linguistic contexts are discussed.

\section{The Notion of Language Policy and Planning}

The notion of language policy and planning emerged in the early $19^{\text {th }}$ century along with the concept of a nation-state, "when one language one nation ideology" was prominent. Many sociolinguists and researchers argue that it is the joint venture of nation-states and linguists that created or labeled languages such as mother-tongue, national, official, native, non-native and many more different categories so that they (nation-states) were able to control and manipulate linguistic behavior of their citizens (MAY, 2001; SHOHAMY, 2006; SPOLSKY, 2009).

It was mainly after World War IIthat many new independent nationstates emerged, with increasingly bilingual and multilingual policies, but most of them tried to maintain status-quos by adopting the former colonial languages, mostly in Asia and Africa. Most of these newly independent states followed the same old path of their former colonies by adopting the colonizer's educational policies in general and language polices in particular (SHOHAMY, 2006; SPOLSKY, 2009; WRIGHT, 2004). Some of the examples from Asia could be Cambodia and Vietnam, where French remained as an official language, and also India, where English was kept as an official language along with Hindi. Similarly, in Africa, many new nation-states kept French as their official language, such as Botswana, Burundi, Cameroon, Mali, Niger and Rwanda (BROCK-UTNE, 2008; KAMWANGAMALU, 2010).

On the other hand, Spolsky (2009) argues that there are four major factors that determine language policy of a nation-state: the sociolinguistic ecology (language practices), a set of beliefs (language ideology) relating language to national identity, the effects of globalization (the pull towards international languages, especially English), and pressure for attention to the rights of indigenous or migrant linguistic minorities. These factors have shaped the current bilingual and multilingual education complex in many countries, especially in Himalayan regions and influenced their language policies and practices. Wright (2004) argues that the residual legacy of nationalism, the perception that bilingualism is a disadvantage and is to be avoided, is fading as more people become bilingual to function at the supra-and international levels. She further states that national minorities in non-English-speaking countries are now likely to be bilingual or multilingual. 


\section{The Concept of Mother Tongue Education}

In1953, UNESCO brought its declaration on the use of vernacular languages in education, given the above stated scenarios. The UNESCO declaration was based on worldwide surveys of classroom instructions where researchers found that in most cases media of instructions were dominant languages of the nation-states or former colonial languages were used and minority and indigenous languages were discarded as mere dialects or local vernaculars. As a result, they emphasized the use of vernaculars and local minority languages (mother-tongues) instructions in place of the so-called languages of wider communication or lingua-franca, to give equal access to education to all. By emphasizing the importance of mother-tongue, it was stated:

Mother-tongue instruction should be the best way for children to learn as it bridges the gap between home language and language of instruction. Every language is sufficient enough to give high cognitive skills to its users and there are no major or minor languages. Therefore, mother-tongue instruction should be extended as long as possible. A LinguaFranca or a language of wider communication cannot be a substitute for the mother-tongue, and it should be avoided until the child fully acquired their mother-tongue (UNESCO, 1953, p. 11).

It is worthwhile to note that UNESCO declaration of 1953 proposed that "education is best carried on through the mother tongue of a pupil" (p. 6) by stating that the mother tongue plays a huge role in the defining of culture, identity, and learning new knowledge. It further stated that "a child will find it difficult to grasp any new concept which is so alien to his cultural environment that it cannot readily find expression in his mother tongue... every effort should be made to provide education in the mother tongue" (p. 47).

However, it was also acknowledged by UNESCO declaration (1953) that the concept of mother-tongue was not straightforward and there were many languages which did not have even scripts and literary texts available at all. In this regard, it is important to note that UNESCO has also reiterated its stand on the use of mother-tongue in its 2003 education position paper. UNESCO education position paper (2003) not only has emphasized mothertongue education, but also has recommended the use of national and official languages of wider communication, along with some global languages, so that indigenous and marginal communities can be able to participate and contribute for large part of the society (UNESCO, 2003). 
So it is understandable that there are lots of complications for ensuring mother-tongue instruction for all children in many regions of the world. For example, in some situations, mother-tongues of particular groups of children are not recognized by nation-states; in other situations, mother-tongues might not be languages of wider communication and yet in other situations, mothertongues might not have enough literary resources available. In these contexts, some of the most outstanding issues that investigators are facing now include how to categorize mother-tongue, whether or not mother-tongue acquisition helps/hinders literacy in second or third languages, whether or not mothertongue of some children is rich enough to cater needs of learners and whether or not this helps learners to acquire high cognitive skills.

Based on the complexities associated with mother-tongue instruction, it can be argued that educators, policy makers and sociolinguists do not agree on the viability and implication of mother-tongue education. For some, this is the ideal situation because a child can learn fully through his/her mothertongue and he/she also develops higher cognitive skills. But for others, mother-tongue education is not very viable due to several factors, such as lack of materials, absence of written scripts in many languages and dialects that are being spoken in the world, and lack of trained teachers in the mother-tongue education. Meanwhile, the global spread of English has further complicated the notion of mother-tongue education in multilingual contexts.

Hence, it is obvious that the concept of mother-tongue is very complex and it entirely depends on how it is interpreted and by whom and for what purposes. Thus the interpretation of mother-tongue could be different for policy makers, and in social and political contexts of nation-states, and in the "linguistic ecology of the society" (HAUGEN, 1972).

\section{The Concept of Multilingual Education}

In regard to multilingualism and multiculturalism, globalization has become the most significant and widely used term over the past few decades, implying contradictory forces of global homogenization and local hybridity; and global domination and local resistance (AMMON, 2001). In other words, the world has seen many changes in the field of education in the light of information technology and globalization over the past three decades. As a result, the focus of language education has shifted from monolingualism to bilingualism and multilingualism. There are many more bilinguals or multilinguals than monolinguals in the world now (BROEDER; MARTYNIUK, 
2008; DARLING-HAMMOND, 2010; SPOLSKY, 2009; TUCKER, 1999; ZAKARIA, 2011).

Nevertheless, there still remains an incorrect belief that when an additional language is introduced into a curriculum, the child must go back and completely relearn the academic concepts. Contrary to empirical evidence, many policy makers still have characterized bilingual education as a high risk undertaking in that it is necessary to attend to a complex set of interacting educational, sociolinguistic, economic, and political factors (CUMMINS, 2000; PHILLIPSON, 2001; SKUTNABB-KANGAS et al., 2009). Consequently, a majority of children face a language gap between schools and homes that must be bridged (UNESCO, 2003). In this regard, Phillipson (2001) contends that in order to fully take advantage of globalization, each country should learn English as an additional language after the mothertongue, and not to the extent that it endangers one's native language. For Skutnabb-Kangas et al., (2009), discouraging children from developing their mother-tongues is a violation of child rights.

\section{Some Case Studies of Multilingual Policies of South-East-Asia}

In the past few decades, many programs have been launched by nationstates to honor their rich and diverse linguistic heritages of indigenous, minorities and tribal communities, and preserve them for the future generations. In the changed national, regional, and global contexts, indigenous knowledge system, linguistic and cultural heritages have got priority in education practices of nation-states all across the globe. In this regard, the forum of South Asian Nations, South Asian Association for Regional Cooperation (SAARC), which currently has eight members- Afghanistan, Bangladesh, Bhutan, India, Maldives, Nepal, Pakistan, and Sri Lanka-, has recognized the need for preserving the indigenous knowledge systems, cultural heritages and centuries old linguistic diversities of the region by adopting the SAARC Agenda for Culture, 2005.

With reference to honoring and preserving indigenous knowledge and heritage, the major declaration came on March 25, 2007 by People's SAARC Declaration, "Respect and recognize the Identity of South Asian Indigenous Peoples and ensure their social, political, economic and cultural rights in the constitution". Since then, major program initiatives for mother-tongue education for the children of indigenous communities are in top priorities of education and curricular reforms in the SAARC region. 
Here, it is also important to consider linguistically diverse contexts of South Asian region. Given the prolonged history of diverse social, cultural, and multi-ethnic contexts of the region, even some Western scholars have recently portrayed the Himalayan region of South Asia as the paradise of linguistic and cultural diversity on the planet. By referring to the multiethnic and linguistic diversity of the Himalayan region, Mark Turin (2007) writes:

The greater Himalayan region, which extends for $3,500 \mathrm{~km}$ from Afghanistan in the west to Myanmar in the east, sustains over 150 million people and is home to great linguistic diversity and many of Asia's most endangered languages. Moving across the region in alphabetical order, Afghanistan boasts 47 living languages, Bangladesh is home to 39, Bhutan has 24, China, 235, India, 415, Myanmar, 108, Nepal, 123, and Pakistan, 72. The entire Himalayan region is often described as one of the ten biodiversity 'mega centers' of the world. This stretch of mountainous Asia is also home to one-sixth of all human languages, so the area should be thought of as a linguistic and cultural 'mega centre' as well, and an important site for the common heritage of humanity (p. 1).

In light of the above stated national, regional and global scenarios, we would like to present four case studies of multilingual practices of the Himalayan region with reference to Afghanistan, China, India, and Nepal. Given the prolonged history of multiethnic and linguistic diversities of these countries, which are also in the lap of Himalayas, we believe that these case studies offer some insights pertaining to language policies and practices of multilingual contexts.

\section{Afghanistan}

Afghanistan is a multiethnic and multilingual country with two major languages and fifty local languages (ETHNOLOGUE, 2009). However, over the past seven decades, most governments of Afghanistan gave priority to the two major languages of the country, Pashto and Dari only. In terms of language policy of Afghanistan, it has a long history of bilingual policy. In 1936 the then government in charge, led by the late king Zahir Shah, announced Pashto as the national language of Afghanistan by a royal decree (Embassy of Islamic Republic of Afghanistan- Warsaw). In this regard, Jan Mohammad (2003) states that one of the most drastic measures taken by Zahir Shah was proclaiming Pashto as the sole official language of the country. It is important 
to note that Pashto and Dari are two major languages that are also the mothertongues of the two largest ethnic groups of Afghanistan.

Later, the Constitution of Afghanistan 1964 declared both Dari and Pashto as the official languages of the country. However, Pashto was given the status of the sole national language of Afghanistan, as the Article 35 of 1964 Constitution stated "the duty of the state to prepare and implement an effective program for the development and strengthening of the national language of Pashtu." The trend of the recognition of two official languagesPashto and Dari - continued in the subsequent Constitutions of 1976, 1987, and 1990 of Afghanistan. Provided the status of official languages, Pashto and Dari have turned into the languages of power, and they were used as media of instructions in schools and universities, and in government offices. Consequently, speakers of other local and indigenous languages continuously adopted either Dari or Pashto, depending on their localities, in order to associate themselves with the languages of power. As a result, Pashto and Dari languages flourished, whereas the other 50 local and indigenous languages of Afghanistan have largely been ignored by the national governments or used only locally. Now, most of them are in the verge of extinction and perhaps some of them have already become extinct.

After the fall of the Taliban regime in 2001, the new administration ratified a new Constitution in 2004. The Article 16 of the Constitution also recognizes some other local languages, in addition to the two official languages-Pashto and Dari of Afghanistan:

From amongst Pashto, Dari, Uzbeki, Turkmani, Baluchi, Pachaie, Nuristani, Pamiri, and other current languages in the country, Pashto and Dari shall be the official languages of the state. In areas where the majority of the people speak in any one of Uzbeki, Turkmani, Pachaie, Nuristani, Baluchi or Pamiri languages, any of the aforementioned languages, in addition to Pashto and Dari, shall be the third official language, the usage of which shall be regulated by law. The state shall design and apply effective programs to foster and develop all languages of Afghanistan. Usage of all current languages in the country shall be free in press, publications, and mass media. Academic and national administrative terminology and usage in the country shall be preserved.

It is important to note that, in this Constitution, for the first time in Afghanistan, the importance of mother-tongue education has also been acknowledged along with the right to education. The 2004 Constitution has 
recognized education as the right of all Afghan citizens by stating that it is the government's responsibility to ensure education to all, including mothertongue education in local and indigenous languages. As the Article 43 of the 2004 Constitution states:

Education is the right of all citizens of Afghanistan, which shall be offered up to the B.A. level in the state educational institutes free of charge by the state. To expand balanced education as well as to provide mandatory intermediate education throughout Afghanistan, the state shall design and implement effective programs and prepare the ground for teaching mother tongues in areas where they are spoken.

Despite constitutional provision for mother-tongue educationduring 1986-1992, when the Constitution of 1987 and 1990 were ratified and the state obliged itself to take the necessary steps for "generalization of balanced education in mother tongue" (CONSTITUTION, 1987, Article 56), real measures were not taken by the governments to implement the provision of mother-tongue education in the country.

Prior to Karzai administration, the Afghan governments favored only Pashtu and Dari languages. The valuing of one ethnic group's language over the other by those who were in power eventually led the country to ethnicfragmention. The ethnic fragmentation in Afghanistan got further exacerbated in 1978-1979 when the pro-communist factions, People's Democratic Party of Afghanistan(PDPA), took over the power and Mujahiddin factions were formed in neighboring countries- Pakistan and Iran. However, it became salient in the years of Afghan civil war, during 1992-1996, and in the subsequent regime of Taliban. Consequently, many Afghans even today equate ethnicity to language. With reference to the inter-ethnic and interlinguistic relations among Afghans, Sven Gunnar Simonsen (2004, p. 7089) aptly writes:

The history of inter-ethnic relations in Afghanistan is one of coexistence, tolerance and pride in diversity, but also of unequal opportunities and conflict. Afghans are reluctant to define the conflicts that have riven their country in recent years in ethnic terms. If speaking broadly, they will often distinguish between the situation among ordinary people and that on the political level. The reasoning, then, will be that there is no real ethnic conflict in the population per se, but that politics, detached from the people, is ethnicised - and has been consciously manipulated to become so by political leaders. This 
image of inter-ethnic relations is in some respects accurate and in other respects too positive.

In line with the Constitutional provisions for mother-tongue education, the Ministry of Education of Afghanistan has initiated some practical measures and, in 2009, the spokesperson of the Ministry Education, Mohammad Asef Nang, announced the inclusion of new books in Turkamani, Uzbaki, Pashai, Baluchi, Pamiri, and Nuristani languages in the school curriculum. However, he also acknowledged that, since these languages have been marginalized for decades, it was difficult to find authors who are capable of writing books in these languages. Nang in particular cited the Pamiri language and said that the Ministry of Education failed to find any author who could write books in Pamiri language (<www.bbc.co.uk/persian/afghanistan>).

Nonetheless, the recent initiations of the Karzai administration for mother tongue education are encouraging for valuing local and indigenous languages and in safeguarding and maintaining the other languages of the country. This is not only a genuine gesture toward maintaining and preserving local languages but this also indicates that the new government is trying to unite different tribes and ethnic groups of Afghanistan. The various ethnicities of Afghanistan have lived side by side for the hundreds of years and there are thousands of families who have both Pashto and Dari as their (mother) tongues. However, unfortunately the decades of war and conflict not only destroyed the physical infrastructure of the country, but also ruined the social fabric of the Afghan society. It is worthwhile to cite Simonsen (2004, p. 710) who notes that

[a]t the frontlines all participating factions could be easily identified in ethnic terms: Hekmatyar'sHezb-e-Islami (and later the Taliban) as Pashtun, Rabbani's and Massoud'sJamiat-e-Islami as Tajik, Hezb-eWahdat as Hazara, and Dostum'sJumbesh-e-MelliIslami as Uzbek. Moreover, each of these leaders exploited ethnicity for his own gain, encouraging spirals of ethicized violence.

The global spread of English is also having its impact in Afghanistan. English was taught as a foreign language (more as a subject) from the seventh grade in the past. Recently, realizing the importance of English language for the country in a globalized world, the Afghan government has brought new provisions for English education in the country. Now English language is being taught from the fourth grade in the place of the seventh grade (AZAMI, 
2009). However, most private schools are teaching English language from the first grade. Many people in the country began to pursue the English language in private English centers.

Furthermore, after the fall of the Taliban regime, many United Nations Offices, NGOs, INGOs and Multi-international Companies have come to Afghanistan to participate in the rebuilding efforts in the country and these entities employ individuals who know English. As a result, many English language centers have opened in all major cities like Kabul, Herat, Balkh, and Nangarhar, and people are learning English in these private institutes in large numbers. However, mushrooming of English language institutes has brought some concerns. Azami (2009) argues that English is taking hold in the country and that apart from the state and non-state support, "an explosion in English language studies, fuelled by the growing dominance of American culture and the financial realities of globalization, is unprecedented."

Besides Afghan government and private sectors, some foreign entities, such as the embassy of the United States and British Council, also support projects and offer grants for English education at Afghan universities and other educational institutions. It is important to note that medium of instruction is either Dari or Pashto language, depending on the localities in universities and higher education institutes. The American University of Afghanistan, which was established in 2006, is the only university in the country that is following American standards and curriculum and its medium of instruction is English.

Nevertheless, Afghan government also promotes other foreign languages in the country, given the changed global contexts. For example, Kabul University, College of Languages and Literature, offers degree programs in several foreign languages, such as Arabic, Spanish, English, French, German, Russian, and Turkish. In 2008, a department of Chinese language was also established at Kabul University, as China is an emerging world leader in foreign direct investment and it invests $\$ 3.5$ billion in copper industries of Afghanistan (KUHN, 2009). It is important to note that just a year before, in 2007, a Chinese firm-Metallurgical Corporation of China (MCC) got the contract of Aynak copper industry of Afghanistan. Chinese investment in such a large amount is unprecedented in the history of Afghanistan and it will have a positive impact on Afghan economy once the production of copper starts. Instruction in English along with Chinese and other foreign language in Afghanistan indicates the importance of languages in bringing the cultures and nations closer. 
Taking the lessons from its past mistakes, when the politicians manipulated languages as tools for their political advantages, and ignored the multi-ethnic cultural and linguistic fabrics of Afghan societies, there needs to be a balanced approach in language policy of Afghanistan.Given the Constitutional provisions for other languages of the country, now the real challenges are the maintenance, reinforcement, and enrichment of all local and indigenous languages, along with its two official (Pashto and Dari) languages in Afghanistan, on the one hand, and the importance of foreign languages, English in particular,on the other.

\section{China}

China is a multilingual and multinational nation with $91.59 \%$ Han people and $8.41 \%$ minority people of 55 groups (China National Statistics Bureau, 2001). Tsung and Cruickshank (2009) categorized minorities into three groups. Korean, Kazak, Mongolian, Tibetan, and Uyghur as the main minority groups that have widely used functional writing systems, so they have used their native languages in bilingual education.Another group including Dai, Jingpo, Lisu, Lahu, and Miao had limited functional writing systems before 1949, so they have also used their native languages more or less in bilingual education. The third group consists of 42 language groups, which have neither fully functional writing systems nor bilingual education. This complexity of language system and language use has challenged language education policy and practices in the context of globalization.

Formal bilingual education began at the turn of the $20^{\text {th }}$ century, when the Qing government opened some bilingual schools that recruited only social elites of the minority groups both in major cities and minority regions (FENG, 2005). The new China founded in 1949 boosted schools for minorities that were self-governed by local leaders. Until 1957, the centralized government created written languages for those minority groups that did not have written but spoken language (FENG, 2005; MA, 2007). The political equality of all nationalities was stressed so that ethnic minorities' languages served as a basic political right of minority peoples and maintained equal and legitimate status so that more than 10 minorities invented their written language with the support of linguists. However, despite increased number of schools in minority regions and the recognition of minority languages in education, China's bilingual education policies did not materialize until the 1980s, when the government brought new policies for minority education and 
thereafter bilingual education policies and programs developed and implemented. China's Constitution (1982) enshrines the freedom to use and develop other languages and cultures: "each nationality has the freedom to use and develop its own language and writing system" (Article 4). These articles demonstrated the emphasis on the values of minorities' language education. Nonetheless, the government "promotes a common language to be used throughout the country" (Article 19). Accordingly, Article 6 of the Compulsory Education Law further specifies that schools should endorse the use of Mandarin as the common language in China. Thus Articles 19 and 6 indicated the government's purpose for minority education that should put Chinese learning into the first place.

Bilingual education in China originally means schooling in which minority and majority languages are used as teaching media, or taught to any extent (TSUNG; CRUICKSHANK, 2009). According to Feng (2005), traditional bilingual education refers to minority groups' education in both Chinese and minority languages, but this bilingual education was operated for minorities who had developed their own spoken and written languages. The purpose of this type of bilingual education is "to create a bicultural identity (minority cultural identity and political or citizenship allegiance to the state" (p. 535).

With national uniform policy for minority education, the bilingual education policies have emphasized development of bilingual teaching in ethnic regions in elementary and secondary schools. It is not difficult to understand why more than two decades ago China adopted the policy "Min-Han Jiantong" (Mastery of both native language and Chinese), which means that individuals should master their native languages and understand their own cultures (Min); but they should also be linguistically competent in Chinese language and understand the dominant Han culture. As Feng (2005) argues, "Min-Han Jiantong" ideology, especially adopted in Xinjiang and Tibet, emphasizes the importance of both high-level Chinese and minority groups' native languages.

Although the "Min-Han Jiantong" policy appears to respect bilingual education, unfortunately, there existed a lot of problems with the implementation of the policies. The lack of funding and highly qualified bilingual teachers is impeding the implementation of bilingual education. In this regard, with reference to Tibetan students, $\mathrm{Ma}$ (2007) writes: 
Among the graduates of 2,417 primary schools where Tibetan is used as the language for instruction, only three classes can go on to junior high schools in which instruction is in Tibetan, whereas the overwhelming majority are channeled into preparatory classes for entrance into junior high schools in which instruction is in Chinese (p. 17).

Another reason that prevents bilingual education from being effectively implemented is the unprecedented changes that resulted from economic reform and globalization. The economic development in big cities or developed regions provided opportunities for minorities to make money and live a different life. When minority parents believe that their students should be educated to get opportunities to work in Chinese or English in the globalized world, any policies to differentiate educational opportunities and standards by ethnicity will embrace resistance. The policies would not benefit the minority groups; on the contrary, they would segregate them further from the mainstream society and put them on unfavorable situations. According to Feng (2009, p. 98-99), " $[t]$ here is potentially a vicious cycle in which social stratification can be exacerbated by inappropriate language policies, which may result in more severe inequality English in China in education, and in turn lead to further social and ethnic divisiveness".

It can infer that given the changed national and global situations, where Chinese and English languages have become the tools for minorities to change their lives, minority languages have become more disadvantaged languages compared with Chinese and English. It is important to note that globalization has stimulated English language education in minority regions.

In 2001, the Ministry of Education regulated that third graders should start to learn English, and standards for secondary schools and colleges were also developed. According to the policies issued by the State Council in 2002, in bilingual education, "the relationship between the minority language and the Mandarin Chinese should be correctly managed... English should be offered in regions where favorable conditions exist". With this policy, the notions of SanyuJiantong (trilingualism or mastery of three languages: the minority home language, Chinese and English) and SanyuJiaoyu (trilingual education) appeared in the literature (FENG; SUNUODULA, 2009).

Surprisingly, two studies of Feng and Sunuodula (2009) and Qian (2007) found that the minority students had optimistic expectations for the nationwide promotion of English language education and that they were motivated in English learning when they saw the values of the language. 
Accordingly, Qian (2007) explains that students are motivated to learn English because it is a form of cultural capital that students will use for social promotion, jobs, and become part of mainstream society.

Despite the enacted policies, most minority students do not have the same opportunity to study a foreign language in elementary or secondary schools as Han students in central and developed areas or big cities (FENG, 2005; YANG, 2005). Hu (2003) found that students' proficiency of English among students from the western provinces with large minority communities is lower than that of students in more developed provinces where Han people were dominant. Challenges were reported about minorities' learning of English resulting from lack of resources to cognitive, affective and socio-cultural problems in learning a foreign language (cited in FENG; SUNUODULA, 2009). Because most of their English teachers do not understand their native languages, minority students have to learn English through Chinese, their second language, although Feng's (2005) research found that the use of the native language rather than the second language may help third language learners' thinking and learning process.

Additionally, the trilingual curriculum broadened the gap between Han students and minority students. Feng and Sunuodula (2009) argue that the current English education policies do not create a real opportunity for equality in education but "segregate the minority groups further from mainstream society and put them on an unequal footing for life opportunities" (p. 699). Yang (2005) listed four factors that contributed the stagnating English teaching and learning in minority areas. Funding for teaching facilities and instructional equipment, teacher training and teaching materials is needed. Students do not recognize the values of English learning so they are not motivated to learn English. Learning an L3 is more daunting than learning an L2 because minority students have less time for English learning (YANG, 2005).

Another barrier for implementing this policy is the lack of effective bilingual policies and curricula to support it (FENG, 2005). Although evident accomplishments have been achieved in terms of policy, teaching methodology, textbook publication, and teacher training and levels of literacy, many challenges and barriers exist in bilingual education and research (FENG, 2005). Minority students experienced cultural discontinuities because textbooks in Chinese contain literature on the Han culture, which prevents minority students from associating the learning content with their home culture (MA; XIAO, 2002). 
Nonetheless, globalization has changed the concept of bilingual education as English has become a second language in developed regions. In recent years in political and economic centers such as big cities, coastal areas, and special economic zones developed areas, English and Chinese have been used as the language of instruction. The purpose of this type of bilingual education is "to satisfy the needs of the contemporary society and to respond to the perceived challenges of globalization and internationalization" (FENG, 2005, p. 535).

Globalization also has enlarged the gap between the east and west parts of China and between urban and rural regions. Consequently, English education, as part of bilingual and trilingual education, has furthered contradictions between educational policies and practices. Students and parents prefer English to Chinese for students' job opportunities or going abroad. However, the patriotists and culturists seek to maintain the position of traditional Chinese language and culture. Opportunities for learning and social promotion also have become more unequal for students in urban and rural areas. Feng (2009) identified conflicting relationships between English and Chinese learning for Han students, and among the native language, Chinese as an official language, and English as a third language for minority students. Feng (2009) documented scholars' concerns about the overemphasis on English education which consequently may threaten Chinese language and culture. These scholars advocated the strengthening of Chinese in order to protect national sovereignty and national security (Feng, 2007). This patriotists' and culturists view contradicts with Feng's (2007) utilitarianist's view that English has its values for "accessing the knowledge of sciences and technology in order to facilitate economic development and nation building in general" (p. 90).

The complex contexts are deepened by the complex social, economic, and political elements in different regions. Feng (2009) delineated differences in different aspects such as gaps between developed and underdeveloped regions, variations in opportunities to English education by socio-economic status, and differences between ethnic groups. $\mathrm{Hu}$ (2003) found the differences in students' English proficiency, teaching pedagogy and students learning behavior between schools in coastal regions and inland regions. The regional differences also were embodied in urban and rural schools (WU, 2008). Even within the same region, different resourcing and teacher training and availability, different teacher availability, teaching methods, suitable curriculum, books and resources result in the gap in terms of educational 
experiences and outcomes (TSUNG; CRUICKSHANK, 2009). Zou and Zhang's (2011) study indicated that students' parents of all types of socioeconomic status (SES) in Shanghai gave strong support to their children's English learning and that students' parents' SES may result in further social divisiveness regarding the opportunity for English learning.

However, the popularity of English language education further broadened the gap between minorities and Han students in terms of opportunities for jobs and higher education. So it can be argued that given the complex, multi-faceted language education contexts, more practical, flexible, and multi-purpose language education policies should be developed in order to equalize all students', especially minorities', opportunities for jobs and higher education.

\section{India}

Multilingualism has been the fabric of Indian societies for centuries and India's pluralism manifests in its linguistic diversity. In this respect, National Curriculum Framework (NCF) 2005 of India states that "[ $t$ ]he linguistic diversity of India poses complex challenges but also a range of opportunities" (p. 37).The NCF further states that "India is unique not only in that a large number of languages are spoken here but... There is no other country in the world in which languages from five different language families exist" (p. 37).

It is worthwhile to note that India has recognized the importance of its multi-cultural and multi-ethnic social realities by accepting multilingual educationand recognizingindigenous and minority languages in its Constitution since its independence from the British in 1947. According to the constitutional provisions for the use of languages in India, the use of English as a second official languagewas supposed to be phased-out by 1965 . When an apparent revolution took place against the "Hindi only" policy in some parts of the country in the 1960s, India adopted a policy called the "Three Language Formula" (TLF) in 1968, according to which Hindi is the national language, English is the language for official businesses along with Hindi, and the third language a state-wise recognized language. For example, Gujarati is the language of the Gujarat (Western Indian state), and Telugu is the language of Andhra Pradesh (Southern Indian state).

The Indian Constitution has also provided some safeguards to diverse linguistic and cultural identity of the nation and so as to sustain multilingual India. As the Article 29 of the Constitution states the following about distinct 
identities of indigenous and minority communities, "[A]nysection of the citizens residing in the territory of India or any part thereof having a distinct language, script or culture of its own shall have the right to conserve the same." The Article 30 (1) specifically states about education in indigenous and minority languages, and guarantees indigenous, religious and linguistic minorities the right to sustain their languages and cultures through education: "All minorities, whether based on religion or language, shall have the right to establish and administer educational institutions of their choice."

In addition, India also made its commitment to ensure mother-tongue education to children, including indigenous and minorities (KHUBCHANDANI, 2008; MOHANTY, 2008). Asthe Article 350 (A) of the Constitution states the following about mother-tongue instructions at the primary stage of education to children of the linguistic minorities: "[I]t shall be the endeavor of every State, and of every local authority within the State to provide adequate facilities for instruction in the mother-tongue at the primary stage of education to children belonging to linguistic minority groups." These constitutional safeguards and guarantees are important for sustaining Indiàs linguistic diversity.

However, the question is still unanswered regarding how to define mother-tongue for education purposes. In line with the spirit of the Constitution, the 1951 Indian Census defined mother-tongue "as the language of parents, language of home or language that has been spoken from the cradle" (KHUBCHANDANI, 2001, 2008). Despite the constitutional definition of mother-tongue, recently in some court decisions of Tamilnadu and Karnataka states, the concept of mother tongue has been interpreted in different ways. According to the court verdict of Madras High Court, mother tongue could be more than one for a particular region, such as Tamil and Tulu (local indigenous language) both could be recognized as mother-tongues of some children in Tamilnadu and it is not necessary that the mother-tongue of children must be the language of parents or a family or language of a community (MOHANTY, 2008). With reference to India's language policies in education, UNESCO (2007) states that:

The 3-language formula says a child has to learn the mother tongue/ regional language, Hindi and English. If the medium of instruction is the mother tongue or a regional language, Hindi and English are introduced between Class I and Class IV. Hindi is continued up to Class VIII (end of elementary school) and the child completes high school in English and the mother tongue/regional language. 
In reality, most of Indian children are being taught even today in language(s) that are not their mother-tongues (GUPTA, 2001; HORNBERGER; VAISH, 2008; SKUTNABB-KANGAS et al., 2009). Less than one percent of tribal children in India have any real opportunity for mothertongue instruction (SKUTNABB-KANGASet al., 2009). Hornberger and Vaish (2008) argue that despite Indias egalitarianThree Language Formula (TLF) of 1968, many Indian children are being educated in a language which is not their own language. In some parts of India, mostly in Hindi speaking states (e.g., UP, Bihar, MP, and Rajasthan), English is being taught as a foreign language, while in some other states, mostly in Southern India, English is being taught as a second language. According to UNESCO (2007), "many minority language children continue to speak their mother tongue at home, but learn to read and write in the dominant regional language....against the principle of learning in one's mother tongue contained within the spirit of the3-formula policy."

While Jhingran (2005) points out, over 12 percent children in India suffer severe learning disadvantage because they are denied access to primary education through their mother tongues. A similar concern was reiterated in NCERT's Position Paper on Teaching of Indian Languages (2006) by stating:

It is indeed a pity that educational planners and language policymakers are not able to capitalize on this innate potential of the child. In a country like India, most children arrive in schools with multilingual competence and begin to drop out of the school system because, in addition to several other reasons, the language of the school fails to relate to the languages of their homes and neighborhoods(p. iv).

The position paper further stated that " $[\mathrm{I}] \mathrm{t}$ is with a sense of regret...that the three-language formula has rarely been implemented in its true spirit anywhere in the country" (p. 21).

In light of the above stated language learning and teaching situations in India, the NCERT Position Paper has also emphasized the need for proper educational policies of mother-tongue education and quality teacher training:

It is imperative that we make provisions for education in the mother tongue(s) of the childrenand train teachers to maximize the utilization of the multilingual situation often obtaining in the classroom as a resource rather than a strict implementation of the three-language formula, it is the survival and maintenance of multilingualism that should be at the heart of language planning in this country (NCERT, 2006). 
It is worthwhile to note that the Indian 2001 census reported fifty-seven languages with more than a million speakers and in some areas children speak three or four languages even before going to school. Due to this demographic reality, children have to learn four or five languages by the time they complete primary school (SKUTNABB-KANGASet al., 2009). It is important to note that a country like India cannot afford to implement classroom instruction in its all languages. There are also many other factors that determine whether a language can be a sole medium of instruction or not. Nevertheless, according the $7^{\text {th }}$ All India School Education Survey (AISES) of National Council of Educational Research and Training (NCERT, 2007), there are forty-seven languages being used as media of instructions at one or more than one levels of education.

On the other hand, the NCF (2005) has also strongly emphasized for the implementation of true multilingualism in Indian schools. By referring to the nation's three language formula, it further states, "It is a strategy that should really serve as a launching pad for learning more languages. It needs to be followed both in letter and spirit.... Its primary aim is to promote multilingualism and national harmony" (p. 37). For implementation of true multilingualism in schools, the NCF (2005) also provides some specific guidelines:

- Language teaching needs to be multilingual not only in terms of the number of languages offered to children but also in terms of evolving strategies that would use the multilingual classroom as a resource.

- Home language(s) of children should be the medium of learning in schools.

- If a school does not have provision for teaching in the children home languages(s) at the higher levels, primary school education must still be covered through the home language(s).

- Children will receive multilingual education from the outset. The Three language formula needs to be implemented in its true spirit, promoting multilingual communicative abilities for a multilingual country.

- In the non-Hindi speaking states, children learn Hindi. In the case of Hindi speaking states, children learn a language not spoken in their area. Sanskrit may also be studied as Modern Indian Language (MIL) in addition to these languages.

- At later stages, study of classical and foreign languages may be introduced. (p. 37). 
Nonetheless, implementation of multilingualism is not that easy in India, given the place of the English language at all levels of education. Though English has become indigenized in India like other English speaking countries like Nigeria and Singapore (KACHRU, 1984), it is still a highly contentious issue in Indian society and in politics. Referring to the English language education in India, the NCERT Position Paper on Teaching of English (2006) states that

English is in India today a symbol of people's aspiration for quality in education and a fuller participation in national and international life. Its colonial origins now forgotten or irrelevant, its initial role in independent India, tailored to high education (as a "library language," a "window on the world"), now felt to be insufficiently inclusive socially and linguistically, the current state of English stem from its overwhelming presence on the world stage and the reflection of this in the national arena (p. 3).

However, the Position Paper also acknowledges that "English does not stand alone. It needs to find its place: (a) along with other Indian languages: (i) in regional medium schools: how can children's other languages strengthen English learning? (ii) in English medium schools: how can other Indian languages be valorized, reducing the perceived hegemony of English; (b) in relation to other subjects: A language across the curriculum perspective is perhaps of particular relevance to primary education. Language is best acquired through different meaning-making contexts and hence all teaching in a sense is language teaching" (p. 3-4).

Hence, "The aim of English teaching is the creation of multilinguals who can enrich all our languages; this has been an abiding national vision" (NCERT, 2006, p. 4).

The dilemma of India for English language education is also manifested in the report of National Knowledge Commission (NKC) (2009) of India:

English has been part of our education system for more than a century. Yet English is beyond the reach of most of our young people, which makes for highly unequal access. Indeed, even now, more than one percent of our people use it as a second language, let alone a first language....the time has come for us to teach our people, ordinary people, English as a language in schools....build an inclusive society and transform India into a knowledge society (p. 27). 
Based on all these legal provisions and actual practices, and arguments and counter arguments, it can be inferred that language education in India is as complex as the nation itself, in terms of its demographics. In other words, with the advent of recent globalization, there have been some added complexities in terms of language policies in India. India needs to prepare its aspiring workforce (equipped with English language competency) for global markets on the one hand, and to keep its long cherished multi-ethnic and linguistic diversities through multilingualism, on the other. There needs to be a balanced approach in language policies in India: Hindi and English along local, regional, and indigenous languages need to be taught.

\section{Nepal}

Nepal is a small but multilingual nation. Despite its small size, it is linguistically diverse. According to the 2001 census, there are 92 languages spoken as mother tongues in Nepal. In this respect, it is worthwhile to refer to Turin (2007), who notes that

[i]n Nepal, linguistic and cultural identities are closely interwoven, and many of the country's indigenous peoples define themselves in large part according to the language they speak. Language is often used as a symbolic badge of membership in a particular community, and is a prominent emblem of pride in one's social or ethnic identity (p. 27).

It is important to note that since the restoration of democracy in 1990, the government of Nepal has realized the importance of Mother Tongue (MT) education in consonance with the $1951 \mathrm{UN}$ declaration. Some of the steps the government has taken in this connection are reflected in its laws and acts. For the first time, the Constitution of the Kingdom of Nepal (1990) has made provision for the right to gain primary education through mother tongues. Accordingly, the National Commission for Language Policy (1992) strongly recommended the use of mother tongues as mediums of instruction at the primary level of education. It was followed by the seventh amendment of Education Act (2001) and different policy documents envisaged under the tenth National Plan, such as Education for All (EFA), and Vulnerable Community Development Plan 2004, have opened up the venues for setting up schools which encourage inclusive modalities by way of MT education (NCF, 2007). 
Later, in consonance with the Constitution of the Kingdom of Nepal (1990) and the Education for ALL (EFA) National Program, the Government of Nepal adopted a policy to introduce different mother-tongues as medium of instruction at primary level of education. It is believed that the use of the child's mother-tongue in school will develop a good home-school relationship and relieve him/her from psychological shock as the child can express his/her ideas well and communicate well if the classroom environment in his/her mother tongue and the subjects taught in class are dealt in his/her mother tongue (CUMMINS, 2000). In this context it is relevant to refer to AndersBaer et al. (2008, p. 3), who state that

[T] he dominant language medium of education prevents access to education because of the linguistic, pedagogical and psychological barriers it createsmost indigenous peoples and minorities have to accept subtractive education where they learn a dominant language at the cost of the mother tongue which is displaced, and later often replaced by the dominant language.

Hence, it is important to promote mother-tongue education at primary level in Nepal. It is also important to note that a huge number of children drops out of school in Nepal due to various factors. One of them is the language of instruction, Nepali. Referring to the gap between home languages of children and the language of instruction in Nepal, Skutnabb-Kangas and Dunbar (2010) argue that "it would therefore be appropriate to educate the children in their mother-tongue in order to make the break between home and school as small as possible" (p. 51).

Although the existence of multiple languages in Nepal has long been recognized, there have been many shifts of policy concerning their recognition and usage within the education system. For example, the first education plan (NNEPC, 1956) adopted a policy of language transfer, whereas the second education plan (ARNEC, 1962) proposed Nepali as the medium of instruction in public schools, as did subsequent education plans (NESP, 1971). It was only after the advent of democracy in 1990 that language issues in education came to the forefront. Consequently, the constitution of the Kingdom of Nepal (1990; Article 3:18:2) and the subsequent education plans (NEC, 1992; HEC, 2000) advocated mother tongue education (CRED, 2005; NCED, 2008; TAYLOR, 2010; UNESCO, 2007).

With the JomteinDeclaration (1990) and Dakar Framework for Action (2000), the Government of Nepal endorsed the Education For All (EFA) 
program (2004-09) to ensure equity in quality basic education for all Nepalese children. As a strategy, the EFA program adopted the use of students' mother tongue as the medium of instruction from grades one to three in a monolingual situation while from the grade four onward the medium is Nepali as a strategy for the transitional bilingual education. It has decided to translate textbooks for Social Studies and Arithmetic into five mother tongues: Maithili, Newari, Awadhi, Limbu, and Tamang, as a follow-up action for Mother Tongue (MT) teaching at primary level education (CRED, 2005; NCED, 2008; NCF, 2007; Taylor, 2010; UNESCO, 2007).

Some of the important steps that have already been initiated in Nepal for mother tongue teaching are that during the Basic and Primary Education Project, Phase I (BPEP- I, 1991-2001), seven languages, Newari, Maithili, Tharu, Awadhi, Limbu, Tamang, and Bhojpuri, are introduced at primary level as optional subjects. This measure proved to be a landmark towards the introduction of mother-tongue instruction. Accordingly, teaching/learning materials (textbooks) were also designed and introduced. Later, five other mother-tongues, Sherpa, Chamling, Bantawa, Magar, and Gurung, are introduced (CRED, 2005). Altogether, twelve languages (out of the nineteen languages, based on personal communication with the government officials of Nepal) have so far been introduced as optional subjects in the different primary schools of more than 17 districts (NCF, 2007; UNESCO, 2007).

In Nepal, English was taught as a foreign language from 1854, when Durbar High School was established. However, it was only in 1971 that the "Nepal National Education Plan 1971" formally recognized English as a foreign language along with some other foreign languages such as Chinese, French, Hindi, Japanese, Russian, and Tibetan. Since then, English was being taught from grade four to graduate level courses as a foreign language in Nepalese educational institutes and universities (GIRI, 2009).

After restoration of the multiparty system in 1990, the government of Nepal made the provision for teaching English language from grade one in the place of grade four in 2004. Gradually it would be used as a second language in the Nepalese education system. However, due to perceived inadequacies of the public education system to teach English as a foreign language in particular, parents have invested heavily in private tutoring or language institutes to provide English education to their children (GIRI, 2009). Owing to great dearth of ELT professionals in Nepalese education system in general and the Ministry of Education in particular, and due to lack of ELT experts in policy 
formulation and curriculum designing, Nepal is still not capable of addressing the large number of failures in English at all levels of its education system, every year. In Nepal, ELT at all levels has been considered a lower status due to a number of factors such as lack of appropriate textbooks, qualified teachers, adequate supplementary materials and audio visual aids, physical facilities and suitable environment (GIRI, 2009; TAYLOR, 2010).

Given Nepal's multi-ethnic linguistic diversities, its language policy needs to be pluralistic in scope. There should be a balanced approach in language policies, mother tongues of minority and indigenous communities, along with global languages-English, Hindi, Chinese, and others. Nepal needs to avoid its past one nation one language policy not only to sustain its rich linguistic diversities but also to maximize economic gains through linguistic and cultural heritages of its multi-ethnic societies in a globalized world.

\section{Conclusion}

In this era of globalization, a society that has access to multilingual and multicultural resources can have advantages in its ability to play an important social and economic role on the global stage. As the world becomes a smaller place because of the global economy, language and how it is learned becomes significant (CAMERON, 2002). Moreover, without multilingual practices, a child's right to education through mother-tongue cannot be ensured in multilingual contexts like South-East Asia. As both minority and heritage languages continue to struggle for recognition and preservation, multilingual practices are also equally important for preserving indigenous communities and their heritages from being extinct. There is an urgent need for respecting our diverse culture and language heritages by instigating them into the children through education.

In the selected cases, mother tongue education has been unanimously emphasized as part of cultural education on the one hand, and they all come under UNESCO (2003) multilingual policies category, teaching/learning practices into at least three languages-mother-tongues, national or local or indigenous, and global.

Nonetheless, globalization is influencing mother-tongue education to different extents in different countries. For example, China has experienced unprecedented economic reform and social changes; therefore, the mother tongue education for both Han people and minority groups has been challenged. Additionally, English has made bilingual and multilingual education more complex and difficult to manage. 
Globalization brought about more awareness of the values of indigenous cultures and mother tongues. Meanwhile, it also has brought about the challenges such as the place of English. These cases suggest that it is essential for educators and policy-makers in each nation to reshape the evolution of national language policies in such a way that the rights of all citizens to education in their own mother-tongues should be respected, and the social, cultural, and linguistic resources of multi-ethnic and diverse societies can be sustained and preserved. The cases also call for the UNESCO or other international organizations to further investigate the patterns of language education in many other countries and develop programs that help them to tap their rich linguistic and cultural heritages for betterment societies and nations in the global era.

\section{References}

AFGHANISTAN ONLINE- PAST CONSTITUTIONS.Retrieved from: $<$ http://www.afghan-web.com/politics/>.

AZAMI, D. English takes hold in Afghanistan. BBC News,Kabul, 2009, Jan.12, Retrieved from: <http://news.bbc.co.uk/2/hi/south_asia/7493285.stm>.

BBC PERSIAN SERVICE. Afghanistan indigenous languages are in the verge of extinction, 2009. Retrieved from: <http://www.bbc.co.uk/persian/afghanistan/ 2009/02/090221_a-afg-mother-language-day.shtml>.

BROCK-UTNE, B. Democracy in a multilingual and multicultural society. In:TIMM, L. (Ed.). Mother tongue and bilingual education: A collection of conference papers. Copenhagen: Danish Education Network, 2008, p. 33-42. Retrieved from: <http://www.uddannelsesnetvaerket.dk/rdb/1205421604.pdf>. BROEDER, P.; MARTYNIUK, W. Language education in Europe: The common European framework of reference. In: HORNBERGER, N.; VAN DEUSENSCHOLL,N. (Ed.). Encyclopedia of language and education. New York, NY: Springer, 2008. p. 209-226.

CAMERON, D. Globalization and the teaching of communication skills. In: BLOCK, D.; CAMERON, D. (Ed.). Globalization and language teaching. London, UK: Routledge, 2002. p. 67-82.

CENTRE FOR RESEARCH, EDUCATION AND DEVELOPMENT (CRED) Mother tongue intervention at primary level in Nepal. A Study Report Submitted to Research and Education Information Management Section, Department of Education, Sanothimi, Bhaktapur, Nepal: Author, 2005. 
CHINA NATIONAL STATISTICS BUREAU. 2000 Diwuci Quanguo Renkou Pucha Zhuyao Shuju Gongbao (Di Yi Hao) [The Fifth National Census Key Statistics Communique', n. 1], 2001. Retrieved from: http://news.sohu.com/ 44/98/news 144449844.shtml>.

CUMMINS, J. Language, power, and pedagogy. Bilingual children in the crossfire. Clevedon, UK: Multilingual Matters, 2000.

DAI, Q.; YANYAN, C. Typology of bilingualism and bilingual educationin Chinese minority nationality regions. In: FENG. A. (Ed.). Bilingual education in China: Practices, policies and concepts. Clevedon, UK: Multilingal Matters, 2007. p.5-93.

DE SWAAN, A. Words of the world: The global language system. Cambridge, UK: Polity Press, 2001.

EMBASSY OF THE ISLAMIC REPUBLIC OF AFGHANISTAN-Warsaw. Languages. Retrieved from: <http://www.afghanembassy.com.pl/cms/en/ afghanistan/languages $>$.

ETHNOLOGUE. Languages of the world: Languages of Afghanistan, 2009. Retrieved from: <http://www.ethnologue.com/show_country.asp?name= afghanistan>.

FENG, A. Bilingualism for the minor or the major? An evaluative analysis of parallel conceptions in China. The International Journal of Bilingual Education and Bilingualism, 8 (6), p. 529-23, 2005.

FENG, A. Bilingual education in China: Policies, practices and concepts. Clevedon, UK: Multilingual Matters, 2007.

FENG, A. English in China: Convergence and divergence in policy andpractice. AILA Review, 22, p. 85-102, 2009.

FENG, A.; SUNUODULA, M. Analysing language education policy for China's minority groups in its entirety. International Journal of Bilingual Education and Bilingualism, 12 (6), p. 685-704, 2009.

GIRI, R. A. English in Nepalese education: An analysis of theoretical andcontextual issues for the development of its policy guidelines (Unpublished doctoral dissertation). Melbourne, Australia: Monash University, 2009.

GUPTA, A. F. Realism and imagination in the teaching of English. World Englishes, 20 (3), p. 365-381, 2001.

HAMEL, R. E. Language empires, linguistic imperialism, and the future of global languages. Universidad Autónoma Metropolitana, Department of Anthropology, México, D. F., 2005. Retrieved from: <http://www.hamel.com.mx/ArchivosPDF/Work\%20in\%20Progress/2005\%20Language\%20Empires.pdf>. 
HAUGEN, E. (1972). The ecology of language. Stanford, CA: Stanford University Press. His Majesty Government of Nepal (1971). National Education System Plan (NESP), 1971.

HU, G. English language teaching in China: Regional differences and contributing factors. Journal of Multilingual and Multicultural Development, 24, p. 290-318, 2003.

KACHRU, B. B. The alchemy of English: Social and functional power of nonnative varieties. In: KRAMARAE, C.; SCHULZ, M.; O'BARR, W. M. (Ed.). Language and power. Thousand Oaks, CA: Sage, 1984. p. 176-193.

KAMWANGAMALU, N. Vernacularization, globalization, and language economics in non-English-speaking countries in Africa. Language Problems \& Language Planning, 34 (1), p. 1-23, 2010.

KHUBCHANDANI, L. M. Language demography and language education. In: DASWANI, C. J. (Ed.). Language Education in Multilingual India. New Delhi: UNESCO, p. 3-47, 2001.

KHUBCHANDANI, L. M. Language policy and education in the Indian subcontinent. In: MAY, S.; HORNBERGER, N. H. (Ed.). Encyclopedia of language and education: Language policy and political issues in education. New York, NY: Springer, 2008. p. 369-381.

KUHN,A. (2009). China becomes a player in Afghanistan's future. Retrieved from: <http://www.npr.org/templates/story/story.php?storyId=113967842>. KUMARAVADIVELU, B. Cultural globalization and language education. New Haven, CT: Yale University Press, 2008.

MA, R. Bilingual education for China's ethnic minorities. Chinese Education and Society, 40 (2), p. 9-25, 2007.

MAY, S. Language and minority rights: Ethnicity, nationalism and politics of language. London, UK: Longman, 2001.

MOHD-ASRAF, R. English and Islam: A clash of civilizations? Journal of Language, Identity and Education, 4 (2), p. 103-118, 2005.

MOHAMMAD, J. Official language policy in Afghanistan. 2003. Retrieved from: <http://ccat.sas.upenn.edu/salrc/afghanistan/lgpolicy/JanAfg.html>.

MOHANTY, A. Perpetuating inequality: Language disadvantage and capability deprivation of tribal mother tongue speakers in India. In: HARBERT, W. (Ed.). Language and poverty. Clevedon, UK: Multilingual Matters, 2008. p.102-124. NATIONAL CENTER FOR EDUCATIONAL DEVELOPMENT (NCED). Multilingual language education. Kathmandu: NCED, 2008. 
NATIONAL COUNCIL OF EDUCATIONAL RESEARCH AND TRAINING (NCERT). National Curriculum Framework 2005. New Delhi, India, 2005.

NATIONAL COUNCIL OF EDUCATIONAL RESEARCH AND TRAINING (NCERT). National Focus Group Position Paper on Teaching of English. New Delhi, India, 2006.

NATIONAL COUNCIL OF EDUCATIONAL RESEARCH AND TRAINING (NCERT). Seventh All India School Education Survey. New Delhi, India, 2007.

NATIONAL CURRICULUM FRAMEWORK (NCF) (2007). National Curriculum Framework for School Education in Nepal-2007. Curriculum Development Centre, Sanothimi, Bhaktapur, Nepal.

NATIONAL KNOWLEDGE COMMISSION (NKC). National Knowledge Commission Report to the Nation 2006-2009. Government of India, New Delhi, India, 2009.

NICHOLAS, B. A. Educational policy for first nations in New Brunswick: Continuing linguistic genocide and educational failure or positive linguistic rights and educational success? Educational Policy, 1-39, 2008. Retrieved from: $<$ http://www.educatorsforimmersion.org/LI_pdf/Genocide>.

PHILLIPSON, R. English for globalization or for the world's people? International Review of Education, 47 (3), p. 185-200, 2001.

QIAN, M. Discontinuity and reconstruction: The hidden curriculum in school room instruction in minority-nationality areas. Chinese Education and Society, 40 (2), p. 60-76, 2007.

QIAN, M. Ethnic education should undertake the major historic task of ethnic unity and the possibility of and explorations into the localization of diversified education. Chinese Education and Society, 43 (5), p. 62-76, 2010.

SHOHAMY, E. G. Language policy: Hidden agenda and new approaches. London, UK: Routledge, 2006.

SKUTNABB-KANGAS, T.; DUNBAR, R. Indigenous children's education as linguistic genocide and a crime against humanity? A global view. Gáldučála Journal of Indigenous Peoples Rights, 1. Resource Centre for the Rights of Indigenous Peoples Guovdageaidnu/ Kautokeino, 2010.

SKUTNABB-KANGAS, T.; PHILLIPSON, R.; MOHANTY, A. K.; PANDA, M. (Ed.). Social justice through multilingual education. Bristol, UK: Multilingual Matters, 2009.

SIMONSEN, S.G. Ethnicising Afghanistan?: Inclusion and exclusion in postBonn institution building. Third World Quarterly, 25 (4), p. 707-729, 2004. 
SOUTH ASIAN ASSOCIATION FOR REGIONAL COOPERATION (SAARC).Retrieved from: <www.saarc.org>.

SPOLSKY, B. Language management. New York, NY: Cambridge University Press, 2009.

TAYLOR, S. K. Beyond bilingual education:Multilingual language educationin Nepal. Gist Education and Learning Research Journal, p. 138-154, 2010.

THE CONSTITUTION OF INDIA. Government of India, Ministry of Law and Justice, New Delhi, India, 1949. Retrieved from: <http://lawmin.nic.in/ coi/coiason29july08.pdf>.

TSUNG, T. H. Minorities in China: Language policy and education. Sydney: the University of Sydney, 1999. (Unpublished PhD dissertation).

TSUNG, L. T. H.; CRUICKSHANK, K. Mother tongue and bilingual minority education in China. International Journal of Bilingual Education and Bilingualism, 12 (5), p. 549-563, 2009.

TUCKER, G. R. A global perspective on bilingualism and bilingual education. ERIC: Clearinghouse on languages and linguistics, 1999.

TURIN, M. Linguistic diversity and the preservation of endangered languages: A case study from Nepal. International Centre for Integrated Mountain Development (ICIMOD). ICIMOD Talking Points: Kathmandu, Nepal, 2007. Retrieved from: <http://books.icimod.org>.

UNITED NATIONS EDUCATIONAL, SCIENTIFIC AND CULTURAL ORGANIZATION (UNESCO). The use of vernacular languages in education (Monographson Fundamental Education-VIII). Paris, France: United Nations Educational, Scientific and Cultural Organization, 1953. Retrieved from: $<$ http://unesdoc.unesco.org/images/0000/000028/002897eb.pdf>.

UNESCO. Education in a multilingual world, 2003. Retrieved from: <http:// unesdoc.unesco.org/images/0012/001297/129728e.pdf>.

UNESCO. Mother tongue-based literacy programmes: Case studies of good practice in Asia.

UNESCO Asia and Pacific Regional Bureau for Education: Bangkok, 2007. Retrieved from: <http://unesdoc.unesco.org/images/0015/001517/151793e.pdf>.

US EMBASSY IN KABUL. English language development programs and resources offered by the public affairs section. Retrieved from: <http://kabul.usembassy.gov/ english_language.html>.

WRIGHT, S. Language policy and language planning: from nationalism to globalization. New York, NY: Palgrave Macmillan, 2004. 
WU, Y. A study of disparities of English provision between urban and rural schools in Shiyan and its balancing strategies. Huazhong Normal University, China, 2008. (Unpublished thesis).

YANG, J. English as a third language among China's ethnic minorities. The International Journal of Bilingual Education and Bilingualism, 8 (6), p. 552-566, 2005.

ZHANG, S.China's bilingual education policy and current use of Miao in schools. Chinese Education and Society, 41(6), p. 28-36, 2008.

ZHOU, L.; REED, L. Chinese government documents on teacher education since the 1980s. Journal of Education for Teaching, 31(3), p. 201-213, 2005.

ZHOU, M. The politics of bilingual education and educational levels in ethnic minority communities in China. International Journal of Bilingual Education and Bilingualism, 4 (2), p. 125-149, 2001.

ZAKARIA, F. The post-American world: Release 2.0. New York, NY: W. W. Norton Company, 2011.

ZOU, W.; ZHANG, S. Family background and English learning at compulsory stage in Shanghai. In: FENG, A. (Ed.). English language education across greater China. Clevedon, UK: Multilingual Matters, 2011. p. 189-211.

Recebido em 1/8/2011. Aprovado em 12/2/2012. 